\title{
SOME EXPERIENCES WITH MYELOGRAPHY IN A GENERAL HOSPITAL
}

\author{
Lieutenant Colonel P. M. BRETLAND, M.B., Ch.B., D.M.R.D., F.F.R., R.A.M.C. \\ Consultant Radiologist *
}

Surgeon Lieutenant Commander K. T. HESKETH, M.B., B.S., F.R.C.S. (Ed), R.N. Consultant Orthopaedic Surgeon** British Military Hospital, Singapore

"Seek and ye shall find; knock and it shall be opened unto you".

MYelograpHY is unique, despite certain shortcomings, in that it is the only objective examination that visualises and localises intrusions into the spinal canal. In certain circles it has sometimes been regarded as a hazardous investigation which is properly restricted to neurological units. We wish to suggest that it can be of great value in the evaluation of spinal cord disease in a general hospital-in this case a Military hospital - many thousands of miles from a full-scale neuro-surgical facility.

Myelography was first described in France by Sicard and Forestier (1923), and since then its usefulness has been firmly established. Hampton and Robinson (1936) at the Massachusetts General Hospital, were among the first to correlate radiological and operative findings. Begg, Falconer and McGeorge (1946), from Otago, made a retrospective study of patients in whom operative confirmation was available and showed that it was possible to locate the site of a disc protrusion with considerable accuracy, including its relationship both to the nerve root and the theca.

Its use for the diagnosis of disc lesions provokes a division between those who favour the routine use of contrast radiographs and those who prefer to rely on clinical criteria as a basis for disc excision. O'Connell (1951) recorded only forty myelograms in his series of five hundred operations. He relied on clinical findings supported by plain films and reserved myelography for the atypical cases. Clinical judgement alone is fairly accurate in the cases with typical patterns of root disturbance (Roaf 1959, Schlesinger 1962), but strong support for myelography ' in most cases' comes from Barr (1947), Epstein (1955) Gurdjian et al (1961) and Lansche and Ford (1960). Harmon (1963) supports this view, in order to give the operator the benefit of the positive findings, to clarify confusing cases and to rule out intraspinal tumours and other lumbar pathology. Our attitude has tended to veer towards this latter policy although clinical signs are still the main basis of management in the greater proportion of cases. The number of patients with disc disease investigated in the group we have reviewed, is fairly high for several reasons. First, as a result of an aggressive attitude to chronic low back pain; manpower shortage, especially during active operations, demands rapid investigation and treatment to return men to duty. Further, Gurkha and locally-enlisted personnel must be treated to conclusion, and evacuation of a dependent to the United Kingdom or elsewhere would break up families unnecessarily.

It is some measure of the success of this policy that among the group of patients investigated for disc lesions, only three negative sets of films were seen and even those

*Now Whittington Hospital, London. N. 19

**Now Royal Portsmouth Hospital, Portsmouth. 
have a use in that they allow conservative treatment to be pursued with greater confidence having been satisfied, at least for the time being, that there is no serious cause for anxiety. Among patients with low back pain is an ill-defined group which can provide numerous difficulties in neurological assessment and management, often over a protracted period. In this group myelography is useful and the varied pathology seen results largely from aggressive inquisitiveness.

\section{Material}

Patients were referred for investigation usually because either a neurological deficit was present which could have been due to spinal tumour, or a disc lesion was thought likely but there were anomalous features. In addition, it was desired to treat some of these patients by anterior disc excision, both at cervical and lumbar levels, the spinal canal not being explored. Before doing this, double disc lesions, other pathology or gross sequestration of nuclear disc material must be excluded.

During 1964 and the first half of 1965 , thirty five myelograms (Table 1) were carried

Table 1

Breakdown of Case material.

\begin{tabular}{lcccc}
\hline Type of Patient & $\begin{array}{c}\text { Low Back Pain } \\
\text { and or } \\
\text { Sciatica }\end{array}$ & $\begin{array}{c}\text { Other Spinal } \\
\text { Lesion }\end{array}$ & $\begin{array}{c}\text { Purely } \\
\text { Neurological } \\
\text { Case }\end{array}$ & Total \\
\hline Officers & 1 & - & 4 & 1 \\
\hline $\begin{array}{l}\text { Servicemen } \\
\begin{array}{l}\text { United Kingdom } \\
\text { Based Civilians }\end{array}\end{array}$ & 12 & - & 1 & 16 \\
\hline Wives & 1 & 1 & - & 12 \\
\hline Children & 1 & 1 & 2 & 4 \\
\hline Total & 26 & 2 & 7 & 35 \\
\hline
\end{tabular}

out; of these, thirty two were at the request of the Orthopaedic unit and three were asked for by physicians. Seventeen were Servicemen, twelve were Service wives, two were United Kingdom based civilians, and four were children in three of whom specific problems arising from spina-bifida were investigated. They comprise twenty six cases of low back pain thought to be associated with disc disease plus a number of other specific lesions of interest.

\section{Method}

Six millilitres of Myodil (Glaxo) or Ethiodan (B.D.H.) were used; the technique was that of Swann (1963). Its most important feature is that the radiologist makes the spinal puncture-taking a specimen of cerebro-spinal fluid for analysis-and injects the contrast medium under fluoroscopic control. A film taken during injection shows that the contrast medium can move freely in the sub-arachnoid space (Fig. 1.1). An inadvertant subdural, or extra-arachnoid, injection produces a bizarre appearance which may be wrongly interpreted (Figs. 2.1,2.2) unless a film taken during injection is available (Fig 2.3). 


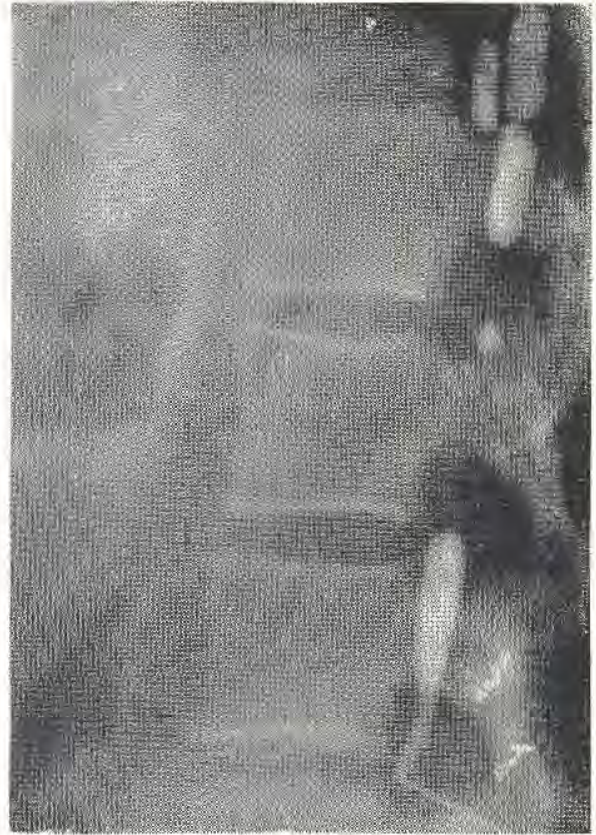

Fig. 1.1: Film taken during injection of contrast medium showing free movement in the sub-arachnoid space.

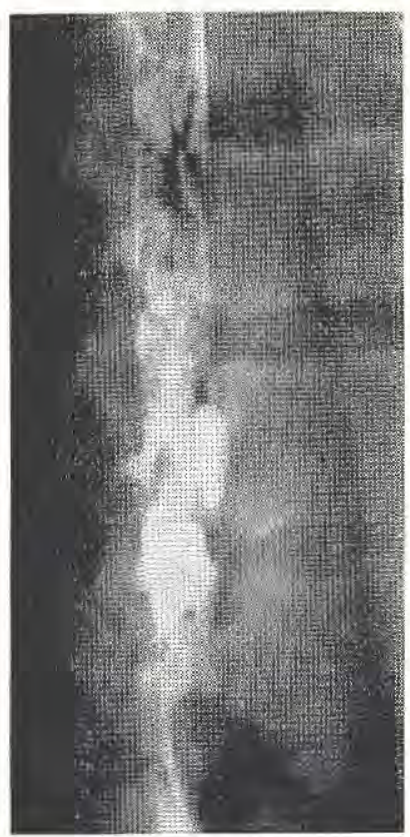

Fig. 2.2: Lateral view of the same, which might well be mistaken for an unusual distribution in the sub-archnoid space.

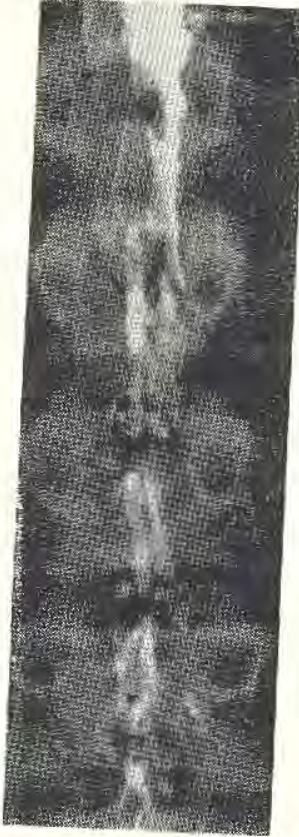

Fig. 2.1: A.P. view of subdural contrast medium.

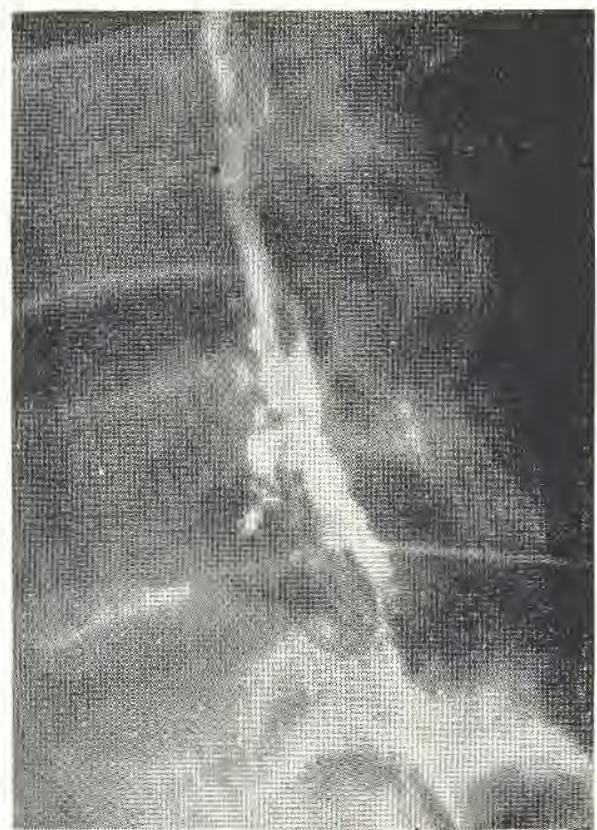

Fig, 2,3: Film taken during injection showing obvious subdural myodil. Nole early moyement down nerve root sheaths. 
This error is liable to occur with a puncture not in the mid-line of the theca, or when myelography is performed less than two weeks after a diagnostic puncture, which may cause dissection between the arachnoid membrane and the dura by leaking cerebrospinal fluid.

Otherwise the technique was conventional, using a standard tilting table (Watson Autonome III) and a locally constructed harness. With the patient prone, the column of contrast media was run down to the sacral sac under fluoroscopic control and then back up through the region of interest which must of course, be previously agreed in detail with the clinican.

It has been proposed that by increasing the quantity of contrast one may reduce the number of false negative results but we have not found this necessary.

\section{Low Back Pain}

\section{Results}

Twenty six cases of low back pain with or without sciatica are detailed in Table II and more succinctly analysed in Table III. The most important fact which emerges from this is that although in sixteen cases the diagnosis of a disc protrusion was confirmed, in six cases, other diagnoses had to be considered as a result of myelography and were demonstrated at operation. Three of these were neurilemmomas, one was a cyst. one had old arachnoiditis and one a localised degeneration of the cord.

\section{(A) Disc Lesions}

Good examples of most of the usual myelographic appearances presented by dise lesions were seen. A classification of these was devised by Begg, Falconer and McGeorge (1946).
(1) Projections (Protrusions)
(2) Intermittent prolapses
$\left\{\begin{array}{c}\text { which } \\ \text { may } \\ b e\end{array}\right.$
(a) Central.
(b) Lateral _ (i) antero-medial (ii) anterior.
(iii) antero-lateral.

(3) Extrusions (Sequestrated disc material)

(4) Scarred discs.

Projections or protrusions are permanent prominences of the discs and are relatively constant. Intermittent prolapses are seen only in certain positions of the spine and these two really only differ in degree. Extrusions or sequestrations are separated disc fragments. Scarred discs are those which are not necessarily prominent but have nerve roots adherent to them.

\section{(1) Protrusions}

(a) Central. "Things are rarely pure and never simple" (Wilde, 1895) and no true, central, lumbar protrusions were seen. In every case the protrusion inclined to one side and several examples are illustrated (Figs 3.1, 3.2, 3.3, 3.4). As described by Begg, Falconer and McGeorge (1946), there is a "waisting" of the column of contrast medium associated with a marked indentation in the lateral view (Figs. 3.1, 3.2) at the level of the disc space. A lesser degree of protrusion gives rise only to a "veiling" as illustrated in Figs. 3.3, 3.4.

(b) Lateral. A lateral disc protrusion antero-medial to the nerve root is shown in Figs. 4.1, 4.2. There is shortening of the nerve root sheath with some indentation of the 


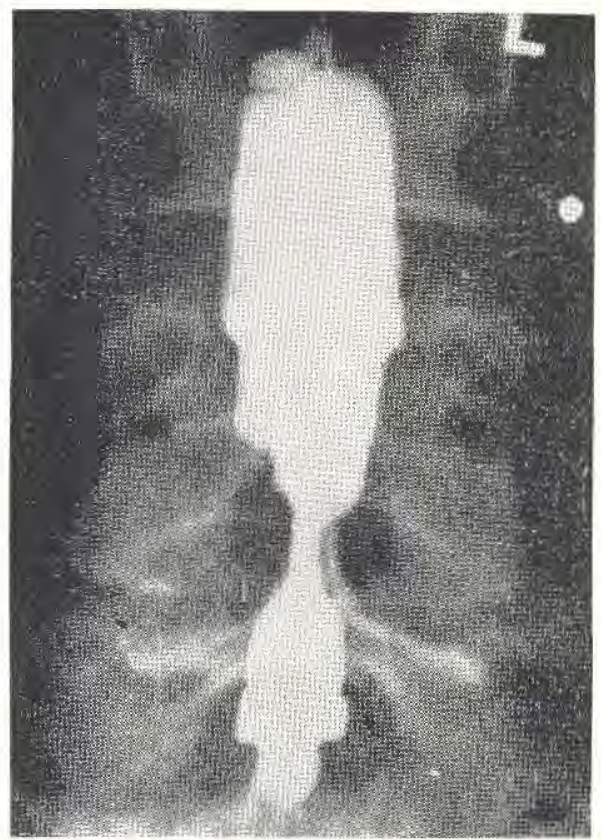

Fig. 3.1: Typical "waisted " appearance of central disc protrusion in A.P. view.

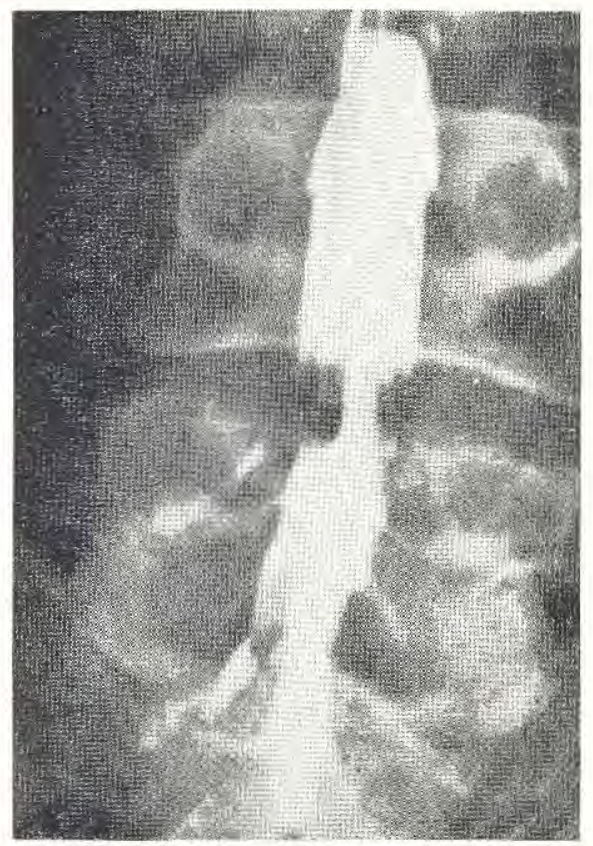

Fig. 3.3: "Veiling" effect of almost central disc protrusion in A.P. view.

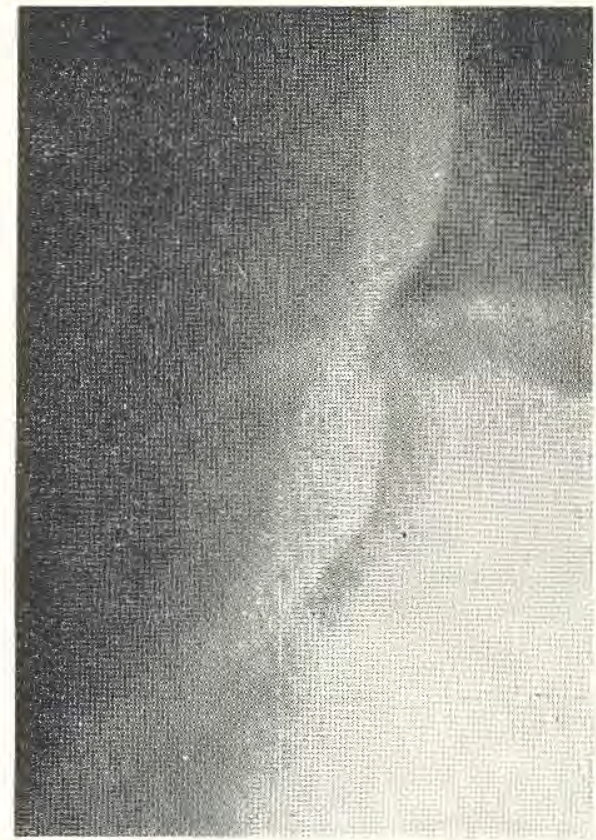

Fig. 3.2: Anterior indentation of theca seen in lateral vicw of central disc protrusion.

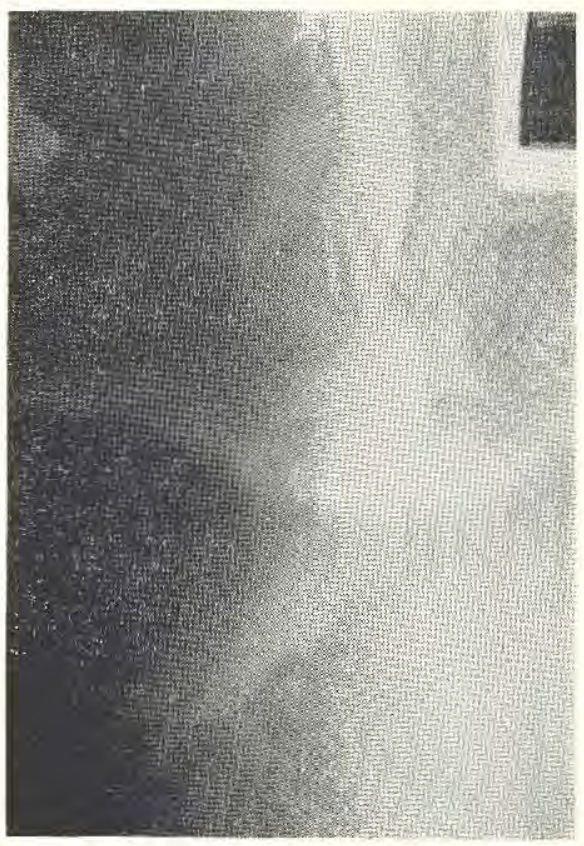

Fig. 3.4: Lateral view of Fig 3.3 showing shallow anterior indentation. 


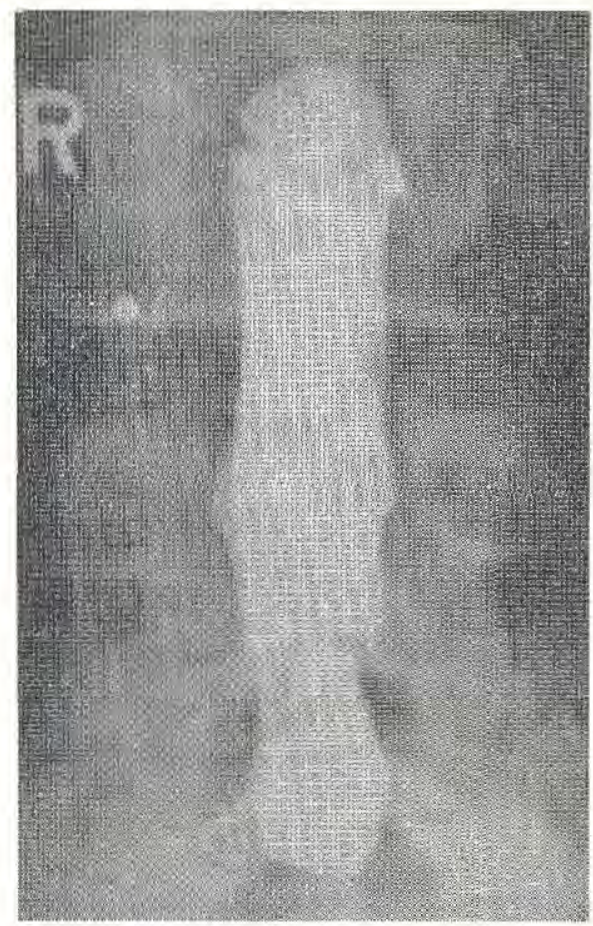

Fig. 4.1: Luteral disc protrusion anteromedial to nerve roots of $L 5$. The column of contrast medium is inden ted and liattened on the R. but not displaced and the nerve rool sheath almost ubliterated.

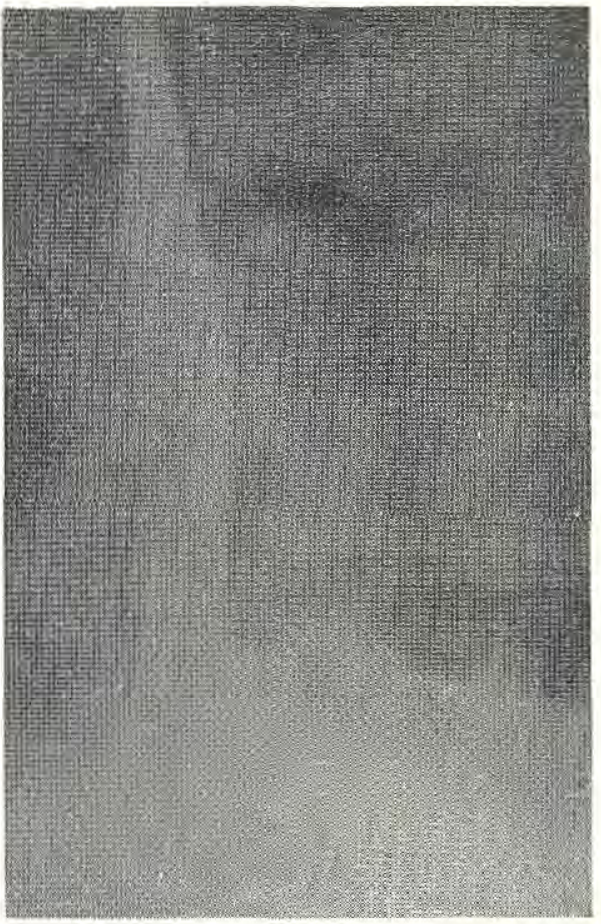

Fig, 4,2; Lateral view of Fig. 4.1: shows only a shallow indentation anteriorly,

main column of contrast in both antero-posterior and lateral views. In this short series we have not seen a pure anterior protrusion where there is no indentation or displacement of the column but shortening of the affected nerve root sheath due to pressure on the nerve alone.

An antero-lateral protrusion is shown in Figs. 5.1, 5.2. The contrast column is displaced to the left and the fifth lumbar and first sacral root sheaths are shortened by the pressure.

At the lumbo-sacral level an extreme lateral protrusion can produce a normal myelogram. Although Case 7 was suspected of being an example of this, she clid not warrant operation: she was rescreened later with this in mind.

(2) Intermittent prolapses were not demonstrated as these are not normally included in the class of patient studied.

(3) Extrusion of muclear material (sequestration) was shown in two cases producing almost complete spinal block in one, which was observed later at operation (Figs. 6.1, $6.2)$.

(4) Scarred discs were not shown.

These appearances of disc prolapse are, when clearly seen, quite unmistakable but the appearances due to other lesions as encountered here are worth comparison since the differences are, in places, somewhat subtle. 


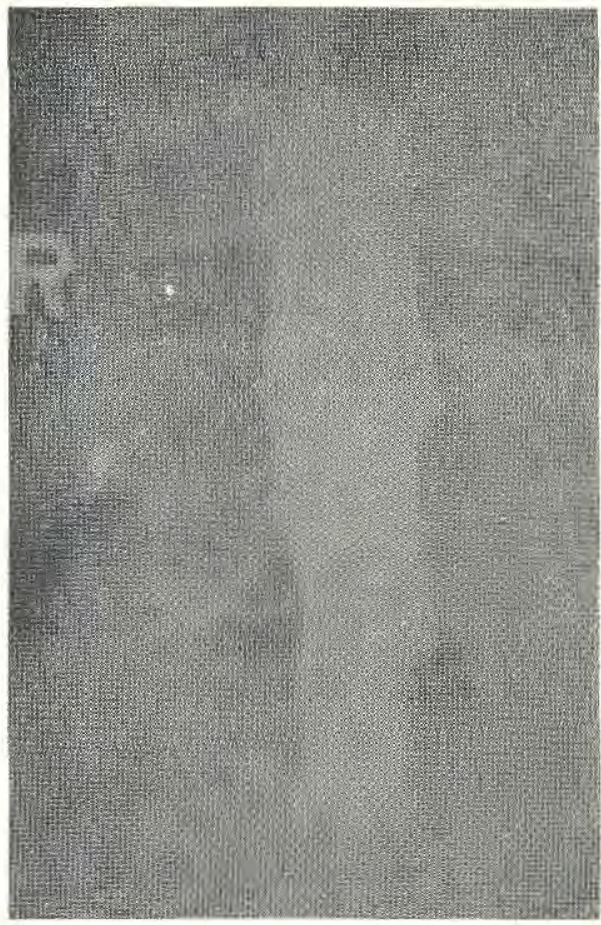

Fig. 5.1: Lateral disc protrusion, anterolateral to the right nerve root of $\mathrm{L} 5$ : in A.P. view the nerve root sheath is obliterated and the column of contrast medium is indented and displaced to the left.

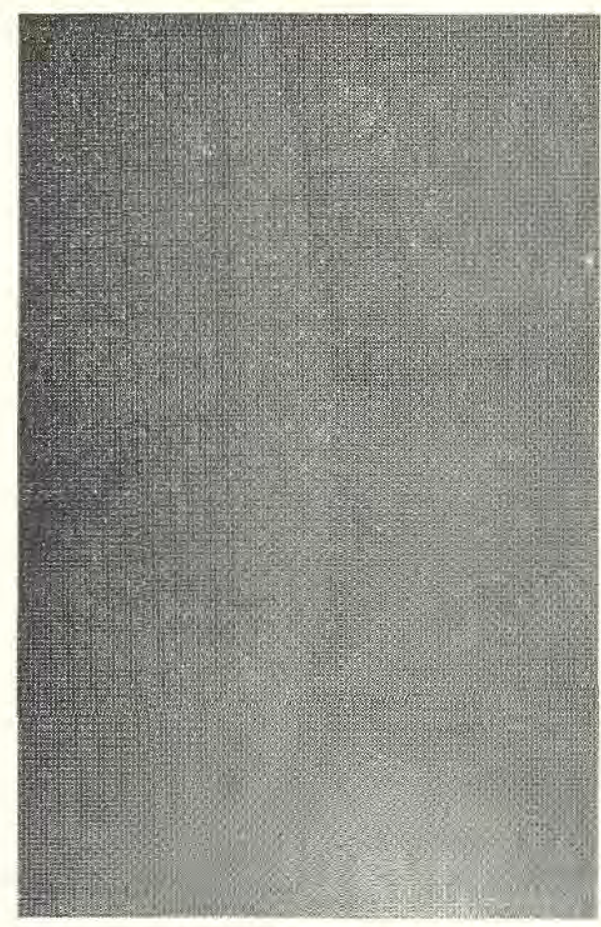

Fig. 5.2: Lateral view of Fig, 5.1 shows no visible anterior indentation so that the protrusion must be well to the side.

(B) Lesions other than discs

Because of the individual nature of these each will be illustrated by short casc summaries.

Case 2. A fifteen year-old girl gave a five year history of low back pain not regarded as significant by a series of doctors in England. There were no physical signs. The myelogram showed a complete intra-dural block at the twelfth thoracic level with classical appearances. (Figs. 7.1, 7.2).

The protein content of the cercbro-spinal fluid taken at myelography was $3,000 \mathrm{mg}$. per cent but this did not interfere with the pictures. It was possible that this could have been an intramedullary tumour so she was evacuated to London where a large paraspinal, intra-thecal neurilemmoma was removed (Fig. 7.3.).

Case 10. A woman aged thirty two with a fourteen-month history of low back pain suddenly developed foot-drop which led to her admission and myelography. This showed a rounded filling defect pressing on the dura posteriorly on the left side (Figs. $8.1,8.2$ ). It was thought to be either due to sequestrated dise material or a tumour. At operation a granular neurilemmoma was removed. 


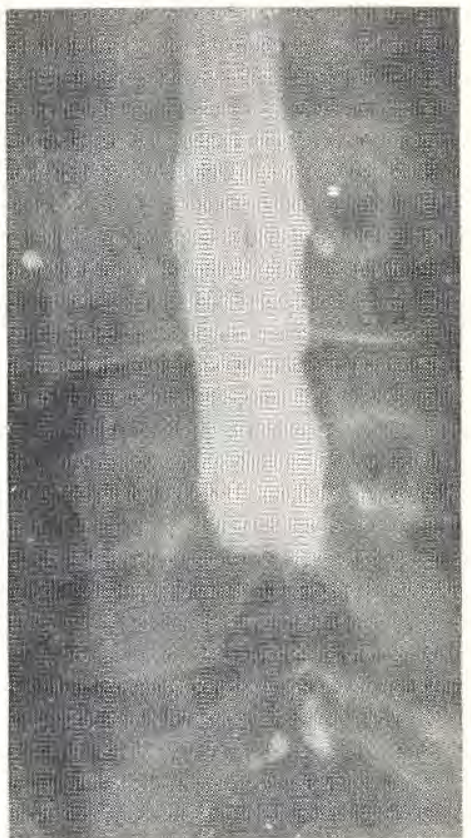

Fig. 6.1: Extruded disc material causing complete block at L4-5; only a trickle of contrast medium would pass distally.

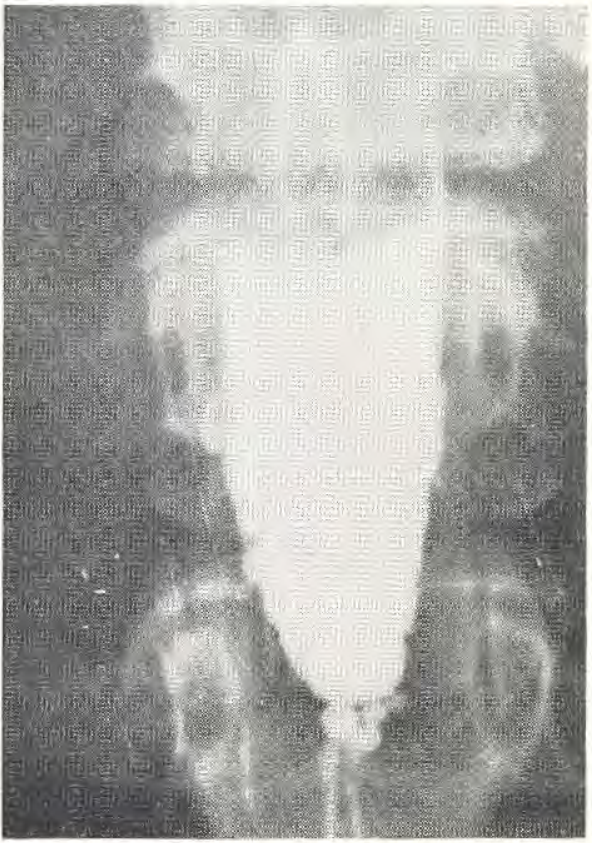

Fig. 7.1: Complete spinal block at $\mathrm{T}$ 12-L 1, apparently intradural (Case 2).

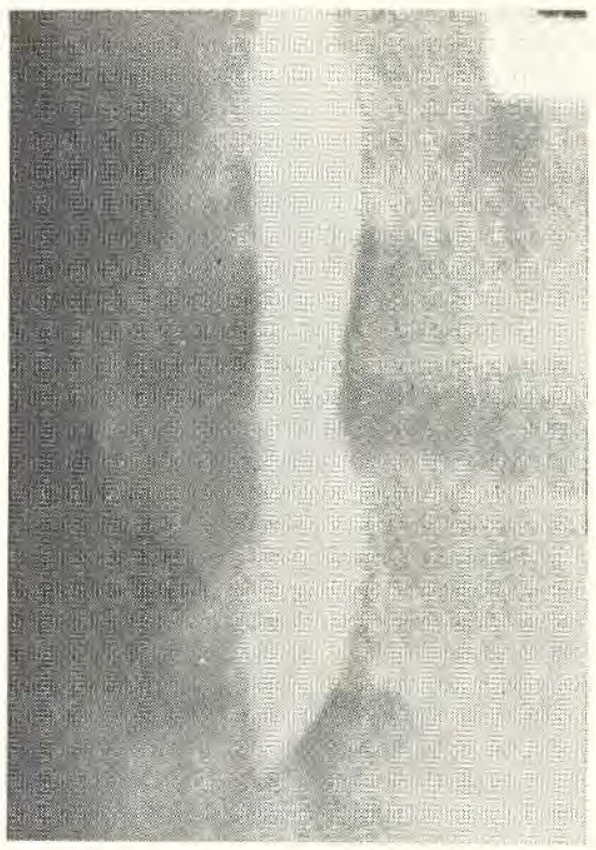

Fig. 6.2: Lateral view of Fig. 6.1 showing oblique cut-off.

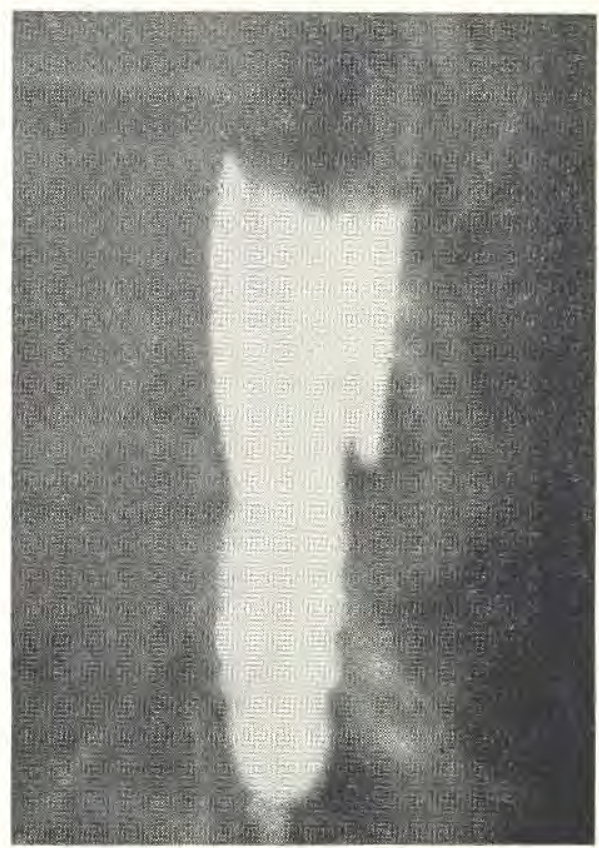

Fig. 7.2; Lateral view of Fig. 7.1 (Case 2). 


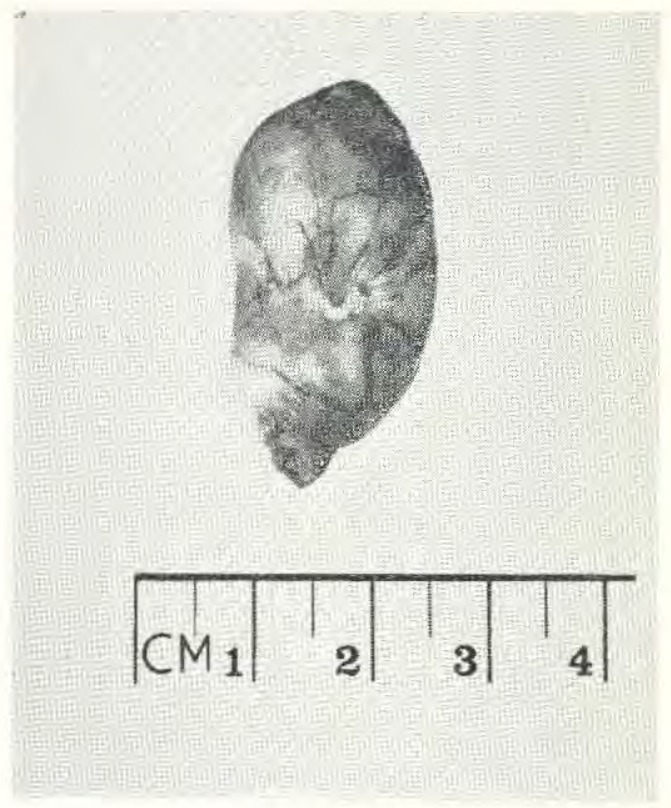

Fig. 7.3: Operation specimen from Case 2; an intradural neurilemmoma.

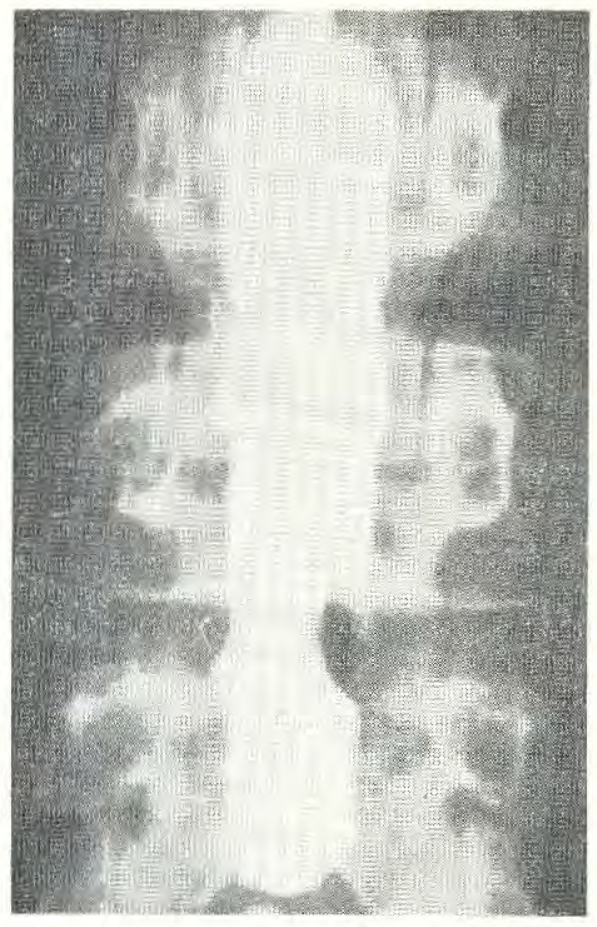

Fig. 8.1: Rounded filling defect seen on left at L 4-5 level in A.P. view (Case 10).

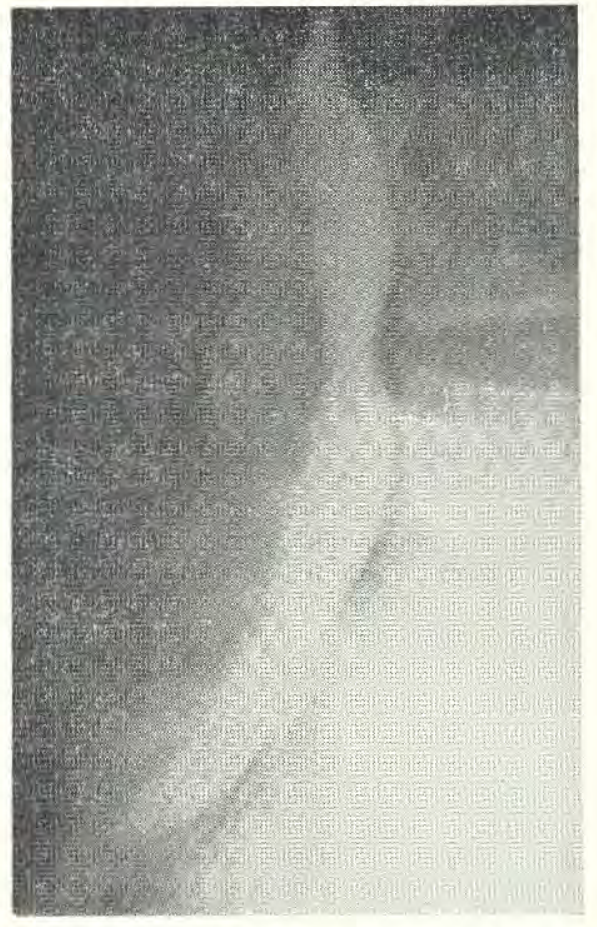

Fig. 8.2: Lateral view of case 10 showing apparent indentation anteriorly but some indentation posteriorly also. 
Case 12. A Gurkha soldier complained of low back pain and bilateral restriction of straight leg raising. The myelogram shows complete block at the mid-lumbar level with a sharp "hollow-ground" cut-off of the column of contrast (Figs. 9.1, 9.2). The appearance suggested a tumour and at operation a large intradural cyst (a degenerated neurilemmoma) was removed.

Case 13. Another Gurkha soldier presented with left sciatica and a myelographic appearance suggesting a lateral protrusion of a disc with anterior pressure on the fifth lumbar root (Figs. 10.1, 10.2). At operation no disc was found but the root was adherent and enclosed in a mass of sear tissue which could not be excised. The root was simply decompressed and he was able to return to duty.

Case 30. A woman aged thirty eight gave a very long history of backache since her youth. The myelogram showed an oblique cut-off of the contrast column with contrast medium trickling down the nerve root sheaths on one side only (Fig. 11.1). At operation, within the theca the nerve roots were matted in a dense mass of tissue and a diagnosis of old arachnioditis was made. Although she was later evacuated to London for a second opinion nothing else was thought necessary and her backache settled. The resemblance to Figs. 6.1, 6.2 in which there was a sequestrated disc is remarkable although there is perhaps a clearer cut-off in the latter case. Such patients of course, warrant

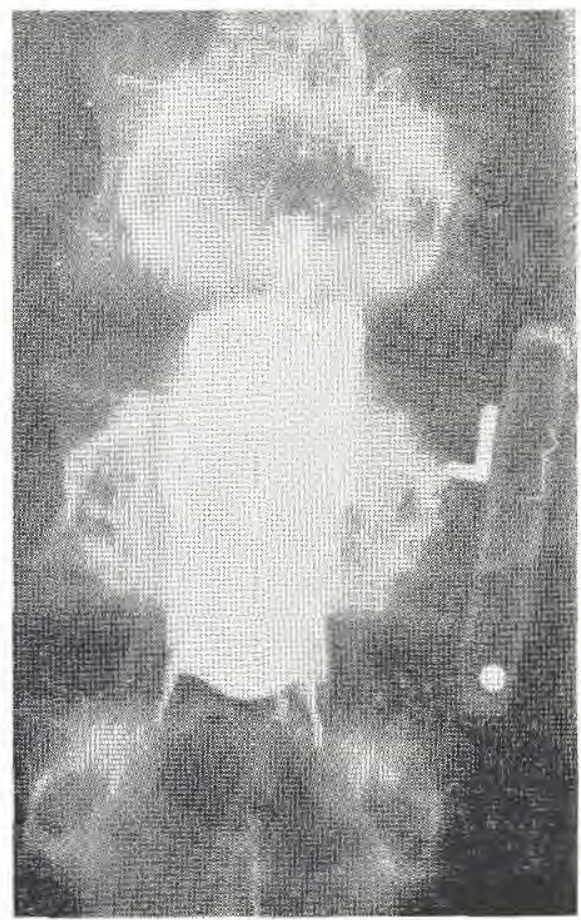

Fig. 9.1

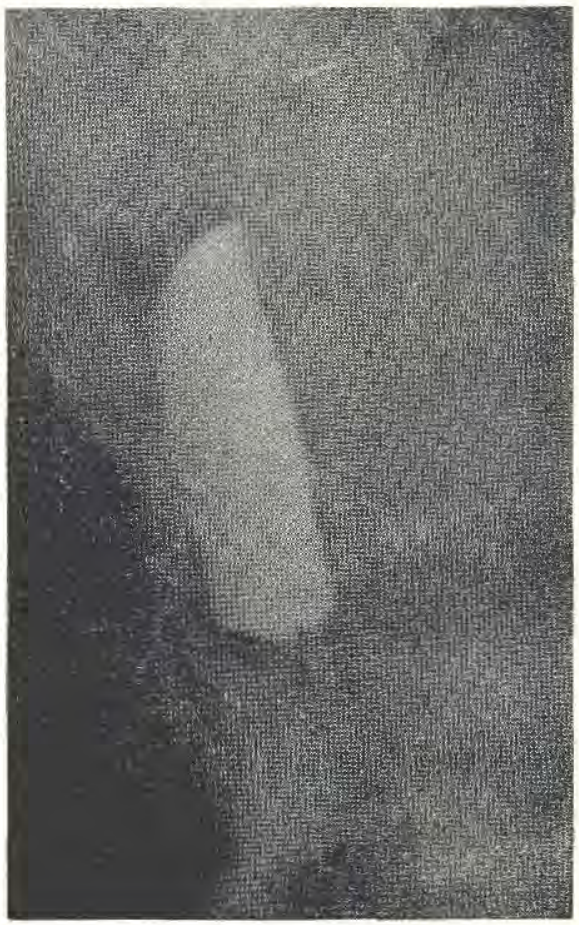

Fig. 9.2

Fig. 9.1: Sharp " Hollow ground" cut off of the column shown in both A.P. and Lateral views (Case and 9.2 12). At operation a neurilemmoma under-going cystic degeneration was shown. 


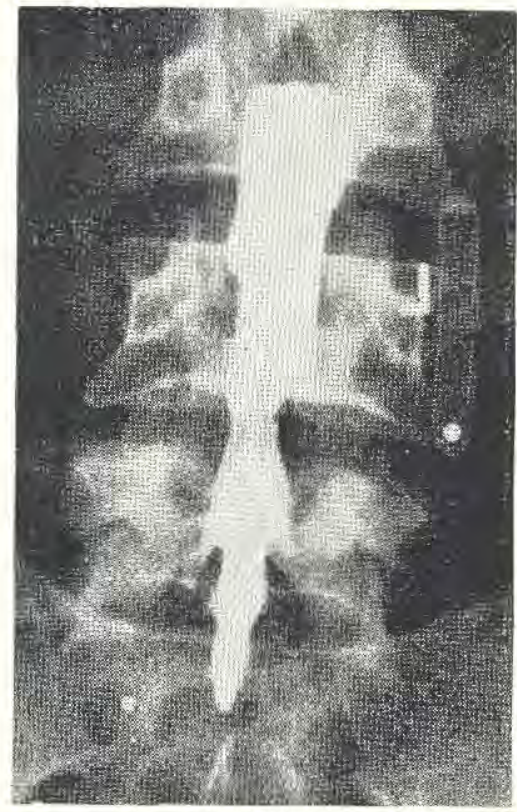

Fig. 10.1: Catse 13, A.P. view shows shortening of nerve rool sheaths of $\mathrm{L} 4$ and 5 on the left; at operation they werc seen to be embedded in a mass of scar tissue.

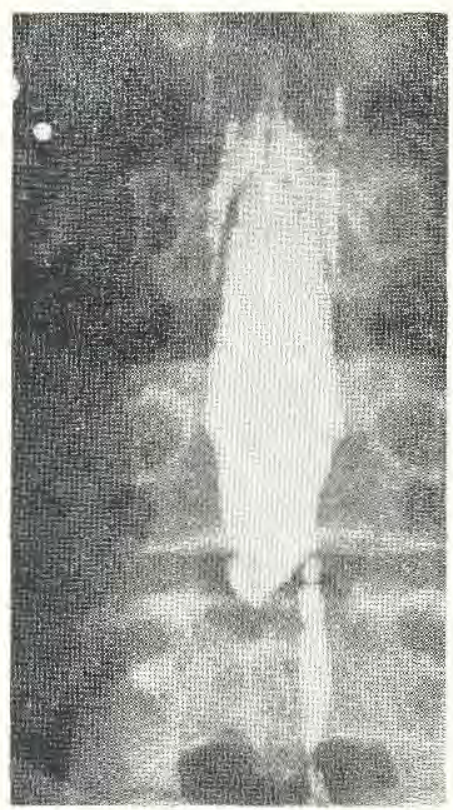

Fig. 11.1: Case 30. A.P. view shows oblique-cut-of of contrast column with a trickle down the left side. (Compare with Fig. 6.1.).

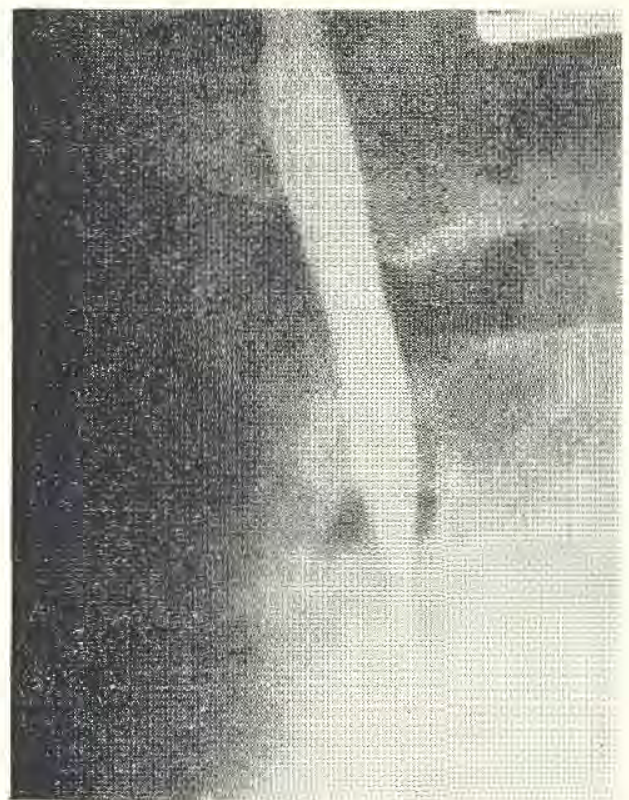

Fig. 10.2: Lateral view of Case 13 shows compression of the theca from in front and bchind.

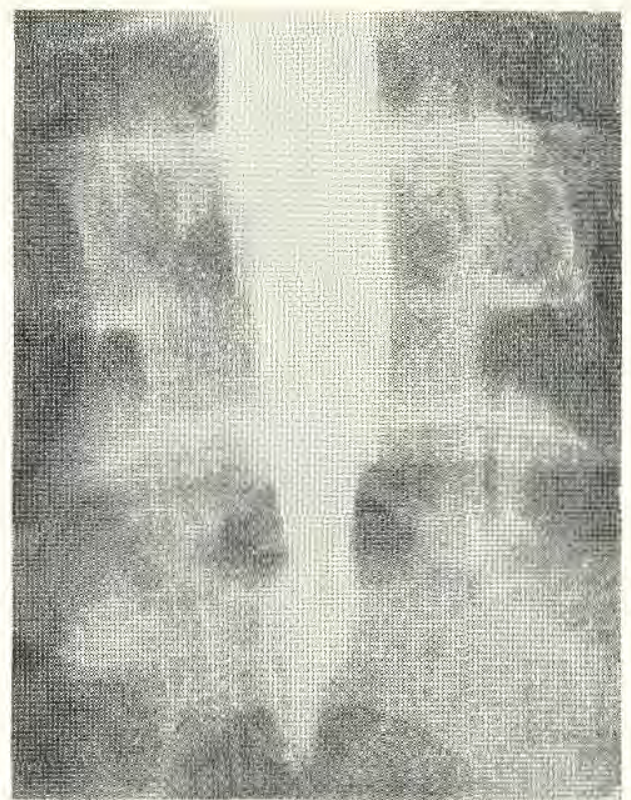

Fig. 12.1: Case 26-the column tapers to a point behind L 5. At operation, arachnoid cysts were present: an extruded fragment was later removed from behind S 1 . 
exploration as the diagnosis cannot possibly be allowed to rest on such subtle radiological distinctions.

Case 26. This sailor presented with pain and cauda-equina symptoms and the myelogram showed tapering of the contrast column at the fifth lumbar level (Fig. 12.1). Exploration disclosed only a cystic appearance of the arachnoid. Insufficient was found to account for the radiological appearance. Rescreening showed virtual return to normal appearances of the theca as far as the first sacral level, though there was some leakage of contrast medium into the planes opened up by the operation. He was re-explored in London later when a small fragment of cartilage was found embedded in the anterior theca at the first sacral level. The findings were difficult to correlate with the myelograms; one might speculate about the effects of extruded disc material.

With this last picture in mind, it is important to draw attention to the normal descent of the contrast column to the second sacral level, for a clean termination of the contrast at the lumbo-sacral junction has been known to be misinterpreted as the limit of a normal theca. Particular care is necessary at this level.

We would like to illustrate one of the difficulties in the cervical spine in which myelography can help.

Case 33. The wife of an Air Force Officer was troubled by cervical root pain not confined to a distribution in keeping with the only bony abnormality seen at the penultimate cervical interval on plain films. Myelography showed a central protrusion at this level but also a significant lateral protrusion at the space below (Fig. 13.1). Both discs were excised and anterior inter-body fusion undertaken with relief of pain.

\section{Neurological Lesions}

Among this group of patients normal appearances were shown in three who were investigated because of amyotrophic lateral sclerosis, a weakness of both legs following injury, and a right-sided paraparesis which recovered on its own. Normal appearances were also seen in a child aged two and a half years with a fever and polyneuropathy.

Three of the other patients are of sufficient interest to describe separately.

Case 8. A Gurkha soldier with a history of recurring meningism, interscapular pain and elevation of the cerebro-spinal fluid protein. The myelogram suggested a long lateral mass with its lower limit at the third thoracic level. At operation a discrete, intramedullary tumour was removed which contained a cyticercus (Hesketh 1965).

Case 17. Was a seven year old boy who had had a lumbo-sacral meningocoele dealt with surgically at birth. He had never gained proper bladder or bowel control and had a limp and poor posture of the lower back. Not surprisingly there were certain emotional features superimposed. The myelogram was of great value here for it demonstrated the problem in great detail. It showed adherance of the lateral part of the theca to the lower end of the abnormal sacrum on the left, and that the theca ended in a large sac with the first and second sacral nerve roots stretched caudally by the tethered membranes, causing them to be reversed and pass upwards to their respective foraminae in the sacrum. Operation was undertaken through an area of grossly disturbed anatomy and scar tissue so that the prior knowledge of the bizzare neurological arrangement was of the utmost importance. The theca and roots were freed and redundant membrane excised to allow the roots to resume a more conventional position. Increased control 
was obtained after operation while he remained in hospital but deterioration took place when he returned home, for reasons beyond our control.

Case 22. Another child also suspected as a case of spinal dysraphism associated with a grossly abnormal sacrum and lumbar spine but the theca was seen to be normal at myelography. This was thought to be an important contribution to the management.

Case 11. A thirty five year old Australian who landed from a liner with a four day old paraplegia with a level at the upper lumbar dermatome. He was convalescing from osteomyelitis of the leg for which he had had antibiotics-and admitted to a heavy fall on the buttocks a day or so before the onset of the paresis which took two days to reach its maximum. Two features here precluded myelography. It was thought that he could well have an extradural abscess and in persons from Australasia hydatid disease of the cord is a cause of acute paraplegia which makes spinal puncture extremely undesirable. If myelography is required in such cases the cisternal route is to be preferred. In this instance the upper lumbar cord was explored without finding any lesion but this then allowed ascending myelography, which demonstrated an intramedullary enlargement of the cord at the level of the twelfth thoracic vertebra (Fig. 14.1). Further exploration showed a necrotic segment of the cord for which nothing could be done. He remained paraplegic and was evacuated to Scotland where he subsequently died. Autopsy revealed similar necrotic areas of varying ages throughout the brain and cord of which the lesion we had seen appeared to have been the first.

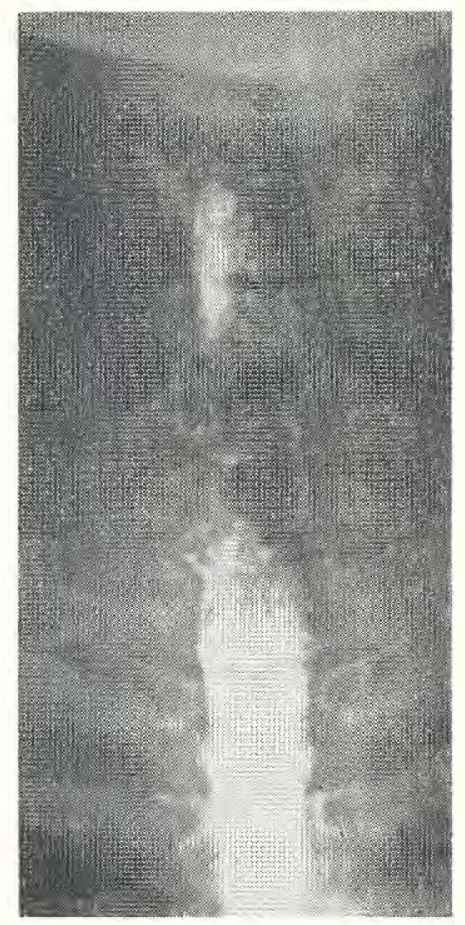

Fig 13.1: Case 33. $\mathrm{A}$ gap in the contrast column in the cervical region involves both C 5-6 and C 6-7 spaces.

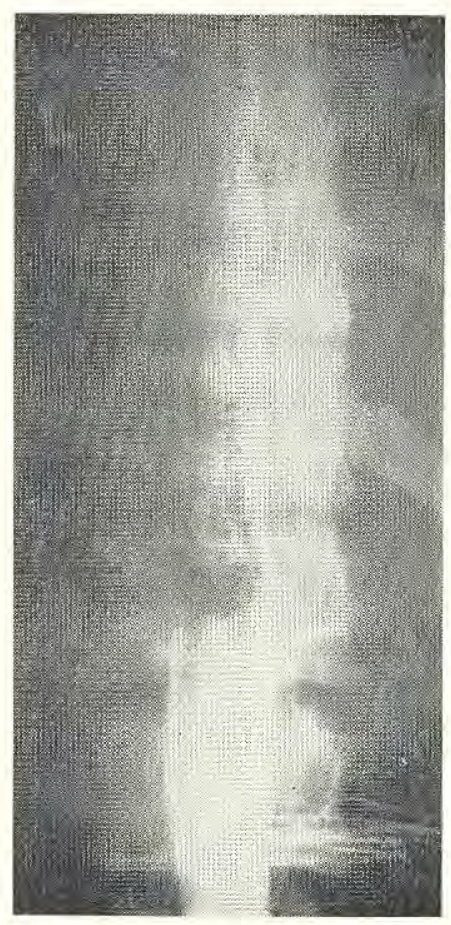

Fig 14.1: Case 11. An intramedullary lesion at the level of T 12. At operation this was swollen necrotic spinal cord. 
TABLE II : CASES OF LOW BACK PAIN AND SCIATICA

\begin{tabular}{|c|c|c|c|c|c|c|c|c|}
\hline $\begin{array}{l}\text { Case } \\
\text { No. }\end{array}$ & Status & Age & Symptom & Duration & Side & Myelographic Findings & $\begin{array}{l}\text { Operative \& pathological } \\
\text { findings where applicable }\end{array}$ & Progress \\
\hline 34 & $\operatorname{Lt}(Q G O)$ & 39 & $\begin{array}{l}\text { Low back pain and } \\
\text { sciatica. About to be } \\
\text { permanently down- } \\
\text { graded P3 L7. }\end{array}$ & $\begin{array}{l}\text { Several } \\
\text { years }\end{array}$ & $\mathbf{R}$ & $\begin{array}{l}\text { Short theca at S1. Lower end displaced } \\
\text { to left and indented just above L4 root } \\
\text { sheath on R. LS root sheath smaller and } \\
\text { higher on } R \text {. Whole theca displaced } \\
\text { backwards. }\end{array}$ & 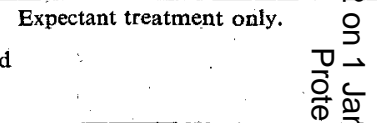 & $\begin{array}{l}\text { Some improvement but } \\
\text { still in P3 L.7 No } \\
\text { sciatica }\end{array}$ \\
\hline 1 & Sgt(RM) & 33 & $\begin{array}{l}\text { Acute sciatica with } \\
\text { marked scoliosis }\end{array}$ & $\begin{array}{l}\text { Periodi-: } \\
\text { cally } \\
\text { (over } 1 \\
\text { year) }\end{array}$ & $\mathbf{L}$ & $\begin{array}{l}\text { Posterior central disc protrusion l } 4-5 \\
\text { Displacement of nerve sheaths. Narrow } \\
\text { canal. }\end{array}$ & $\begin{array}{l}\text { Laminectomy L4. Removal 突 } \\
\text { large L4-L5 disc. }\end{array}$ & $\begin{array}{l}\text { Returned to RM Special } \\
\text { Boat section on full } \\
\text { (very arduous) duty }\end{array}$ \\
\hline 12 & $\begin{array}{l}\text { Dvr } \\
\text { (Gurkha } \\
\text { ASC) }\end{array}$ & 24 & $\begin{array}{l}\text { Low back pain. } \\
\text { SLR : R-L }=30^{\circ}\end{array}$ & 15 month & Both & $\begin{array}{l}\text { L3-4 block; sharp cut-off; thought to } \\
\text { be neoplastic. }\end{array}$ & $\begin{array}{l}\text { Lumbar Laminectomy. Large } \\
\text { intra dural cyst, thin walled, } \\
\text { adherent to nerve roots- } \\
\text { dissected off. Histology- } \\
\text { cystic degeneration in a } \\
\text { neurilemmoma. }\end{array}$ & Did well. \\
\hline 13 & $\begin{array}{l}\text { L/Cpl } \\
\text { (Gurkha) }\end{array}$ & 26 & $\begin{array}{l}\text { Low back pain, } \\
\text { L sciatica }\end{array}$ & & $\mathbf{L}$ & $\begin{array}{l}\text { L4-5 disc on } L \text { involving nerve root } \\
\text { sheath of } L 5 \text {. }\end{array}$ & 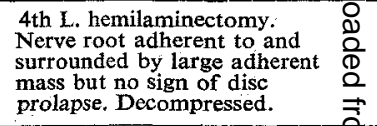 & $\begin{array}{l}\text { Good progress. Returned } \\
\text { to duty } 4 \text { months after } \\
\text { Myelogram. }\end{array}$ \\
\hline 16 & UKBC & 33 & $\begin{array}{l}\text { Pain L leg, buttock } \\
\text { and calf. Decreased } \\
\text { SLR \& AJ, wasted } \\
\text { calf. }\end{array}$ & 1 week & L & $\begin{array}{l}\text { L lateral dise with displacement of } \\
\text { theca. Narrow spinal canal. }\end{array}$ & $\begin{array}{l}3 \\
\frac{3}{2} \\
0 \\
0\end{array}$ & $\begin{array}{l}\text { Conservative treatment } \\
\text { only. Returned to work } \\
\text { and then to U.K. }\end{array}$ \\
\hline 18 & $\begin{array}{l}\text { L/Cpl } \\
\text { RE }\end{array}$ & 19 & . & & & $\begin{array}{l}\text { Multiple disc protrusion. Narrow spinal } \\
\text { canal }\end{array}$ & 昘: & $\begin{array}{l}\text { Pain not relieved, } \\
\text { Returned to U.K. in POP } \\
\text { jacket. Fit } 3 \text { wks } \\
\text { after it was removed. }\end{array}$ \\
\hline 19 & RFA & 26 & , & & & $\begin{array}{l}\text { Discs } \quad \text { L4-5 central } \\
\text { L5-S1 left } \\
\text { Lesser central protrusion } \\
\text { L } 2-3-4\end{array}$ & 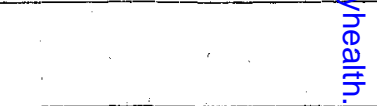 & Evacuated to U.K. \\
\hline 21 & $\begin{array}{l}\text { Spr. } \\
\text { Gurkha } \\
\text { Engr. }\end{array}$ & 21 & $\begin{array}{l}\text { Twisted back on parade. } \\
\text { L. Lumbar pain and } \\
\text { sciatic scoliosis } \\
\text { concave to lef. SLR } \\
\text { R } 80^{\circ} \mathrm{L} 40^{\circ} \text {. Left } \\
\text { AJ }++ \text { with clonus. }\end{array}$ & 3 months & L & $\begin{array}{l}\text { L4-5 protrusion, well marked. L5 nerve } \\
\text { root sheath nipped off } 1 \mathrm{~cm} \text { above disc } \\
\text { space with oval filling defect. }\end{array}$ & $\begin{array}{l}\text { Large L4-5 protrusion with } \\
\text { blackened tip. difficult } \\
\text { clearance. }\end{array}$ & $\begin{array}{l}\text { Returned to duty } 3 \\
\text { months after myelogram. }\end{array}$ \\
\hline 23 & $\begin{array}{l}\text { Cpl. } \\
\text { R. Sigs. }\end{array}$ & 32 & $\begin{array}{l}\text { Injury at water } \\
\text { sking } \\
\text { Sciatica. }\end{array}$ & $\begin{array}{l}3 \text { months } \\
1 \text { month }\end{array}$ & $\mathbf{R}$ & $\begin{array}{l}\text { Slight central protrusion at } \mathrm{L} 4-5 \text { and } \\
\text { L5-S1. Narrow canal. N. Root sheaths } \\
\text { normal. }\end{array}$ & $\frac{1}{2}$ & $\begin{array}{l}\text { Returned to U.K. Some } \\
\text { improvement with POP } \\
\text { jacket. To wear corset. }\end{array}$ \\
\hline 26 & $\underset{\operatorname{man} R N}{L / S e a-}$ & 28 & $\begin{array}{l}\text { Cauda equina syn- } \\
\text { drome saddle } \\
\text { anaesthesia, disturbed } \\
\text { bladder control }\end{array}$ & 2 weeks & $\mathbf{L}$ & $\begin{array}{l}\text { Theca entered only at } L 2-3 \text { space, } \\
\text { tapering off to obliterate at middle of } \\
\text { L5. Displaced back and to } R \text {, apparently } \\
\text { by space-occupying lesion. }\end{array}$ & $\begin{array}{l}\text { Several arachnoid cysts seen } \\
\text { at laminecto ny, broke up on } \\
\text { dissection. }\end{array}$ & $\begin{array}{l}\text { Not improved. Returned } \\
\text { to U.K. At repeat } \\
\text { myelogram theca normal } \\
\text { shape. }\end{array}$ \\
\hline & . & & & & & $\because$ & 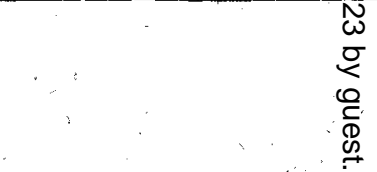 & ", \\
\hline
\end{tabular}




\begin{tabular}{|c|c|c|c|c|c|c|c|c|}
\hline $\begin{array}{l}\text { Case } \\
\text { No. }\end{array}$ & Status & Age & Symptom & Duration & Side & Myelographic Findings & $\begin{array}{l}\text { Operative \& pathologicgp } \\
\text { findings where applicabte }\end{array}$ & Progress \\
\hline 27 & $\begin{array}{l}\text { Sgt } \\
\text { RAOC }\end{array}$ & 29 & Low back pain & ? & $\mathbf{L}$ & $\begin{array}{l}\text { Theca displaced to left at L5-S1 and } \\
\text { nerve root sheath of L4-5 shorter on } R \text {. }\end{array}$ & ì & $\begin{array}{l}\text { Conservative treatment } \\
\text { Refused operation. }\end{array}$ \\
\hline 29 & Inf & 34 & $\begin{array}{l}\text { Low back pain. } \\
\text { R sciatica recently } \\
\text { SLR } 30^{\circ} \text { both sides. }\end{array}$ & 15 years & $\mathbf{R}$ & $\begin{array}{l}\text { Large L4-5-S1 disc with theca displaced } \\
\text { to left obliterating sheath of LS-S1 and } \\
2 \text {, on } R \text {. Extradural mass, probably } \\
\text { sequestrated disc. }\end{array}$ & 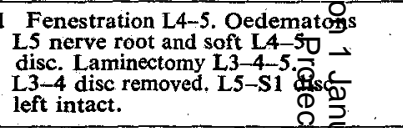 & $\begin{array}{l}\text { Good progress after } \\
\text { operation. }\end{array}$ \\
\hline 32 & $\begin{array}{l}\text { Sgt } \\
\text { RAVC }\end{array}$ & 25 & $\begin{array}{l}\text { Severe sciatica for } \\
2-3 \text { years. }\end{array}$ & $\begin{array}{l}2-3 \\
\text { years }\end{array}$ & Both & $\begin{array}{l}\text { Extra-dural anterior mass cutting off } \\
\text { theca anteriorly at level of } L 4-5 \text { disc } \\
\text { space. Probably sequestrated disc. }\end{array}$ & 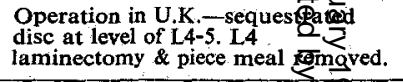 & Much improved. \\
\hline 35 & $\begin{array}{l}\text { Rfn } \\
\text { (Gurkha } \\
\text { Inf) }\end{array}$ & 21 & $\begin{array}{l}\text { Acute attack of low } \\
\text { back pain \& R } \\
\text { Sciatica. Acute attack } \\
1 \text { year ago }\end{array}$ & 1 year & $\mathbf{R}$ & $\begin{array}{l}\text { Theca displaced posteriorly and to left. } \\
\text { obliterated at L4-5 space. Gross } \\
\text { deformity of sheaths of L5 and S1. }\end{array}$ & $\begin{array}{l}\text { Laminectomy } \\
\text { Big L4-5 protrusion. }\end{array}$ & $\begin{array}{l}\text { Much improved. } \\
\text { Symptom free with } \\
\text { strong back. }\end{array}$ \\
\hline Female & $\begin{array}{l}\text { W/O Sgt } \\
\text { RM }\end{array}$ & 25 & Back ache ? Urinary & 3 months & & Normal & Ð & Gynaecological case \\
\hline 7 & $\begin{array}{l}\text { W/O } \\
\text { UKBC }\end{array}$ & 40 & $\begin{array}{l}\text { Low back pain and } \\
\text { Sciatica }\end{array}$ & 18 months & $\mathbf{R}$ & Normal & $\begin{array}{l}\frac{0}{1} \\
\frac{2}{\equiv}\end{array}$ & $\begin{array}{l}\text { Settled on conservative } \\
\text { treatment eventually, though } \\
\text { re-admitted and rescreened. }\end{array}$ \\
\hline 9 & $\begin{array}{l}\text { W/O } \\
\text { S/Ldr } \\
\text { RAF }\end{array}$ & & $\begin{array}{l}\text { Low back pain and } \\
\text { sciatica } \\
\left(\mathbf{R} t . A J_{--}\right)\end{array}$ & 2 years & $\mathbf{R}$ & L4-5 disc protrusion & $\begin{array}{l}\frac{0}{3} \\
\frac{2}{2}\end{array}$ & $\begin{array}{l}\text { Conservative treatment (belt) } \\
\text { one year later, weak } R \text { foot, } \\
\text { good movements, no pain. }\end{array}$ \\
\hline 10 & $\begin{array}{l}\text { W/O } \\
\text { SBPO } \\
\text { RN }\end{array}$ & 32 & $\begin{array}{l}\text { Low back pain } \\
\text { Left foot drop. }\end{array}$ & $\begin{array}{l}14 \text { years } \\
2 \text { weeks }\end{array}$ & $\mathbf{L}$ & $\begin{array}{l}\text { Rounded filling defects pressing on } \\
\text { dura from left and behind and involv- } \\
\text { ing } \mathrm{N} \text {. root-sequestrated disc or } \\
\text { tumour. }\end{array}$ & $\begin{array}{l}\text { Laminectomy. Lump of } \\
\text { granular material pressing on } \\
\text { 4th } L \text {. root removed-extradur } \\
\text { Pathology-neurilemmoma. }\end{array}$ & Full recovery. \\
\hline 15 & $\begin{array}{l}\text { W/O } \\
\text { CPO } \\
\text { RN }\end{array}$ & 35 & $\begin{array}{l}\text { Back pain on bending } \\
5 \text { years ago, repeated } \\
\text { Dec. } 63 \text {. SLR } 30^{\circ} \\
\text { both sides. }\end{array}$ & 5 yrs. & Both & Normal & Conservative treatment. & Improved. \\
\hline 20 & $\begin{array}{l}\text { W/O } \\
\text { UKBC }\end{array}$ & 32 & $\begin{array}{l}\text { Low back pain, } L \text { hip } \\
\text { pain \& pain down front } \\
\text { of } L \text { leg. }\end{array}$ & 3 yrs. & & $\begin{array}{l}\text { L4-5 disc to left. Displacement of } \\
\text { theca and indentation of dura. }\end{array}$ & $\begin{array}{l}\text { Anterior disc excision and } \\
\text { inter-body fusion. }\end{array}$ & Much improved. \\
\hline 20 & $\begin{array}{l}\text { W/O } \\
\text { UKBC }\end{array}$ & 32 & $\begin{array}{l}\text { Low back pain, } L \text { hip } \\
\text { pain \& pain down front } \\
\text { of } L \text { leg. }\end{array}$ & 3 yrs. & & $\begin{array}{l}\text { L4-5 disc to left. Displacement of } \\
\text { theca and indentation of dura. }\end{array}$ & $\begin{array}{l}\text { Anterior disc excision and } \\
\text { inter-body fusion. }\end{array}$ & Much improved \\
\hline 24 & $\begin{array}{l}\text { W/O } \\
\text { F1/Lt } \\
\text { RAF }\end{array}$ & 24 & Low back pain. & $5-7$ years. & - & No significant dise protrusion. & $\begin{array}{ll}\text { Anterior spinal fusion L4-5 } & \frac{O}{3} \\
\text { and L5-Si. } & \frac{7}{O} \\
\end{array}$ & $\begin{array}{l}\text { Improved } \\
\text { Eventually pain free. }\end{array}$ \\
\hline 25 & $\begin{array}{l}\text { W/O } \\
\text { SPO } \\
\text { RN }\end{array}$ & 29 & $\begin{array}{l}\text { Low back pain, sudden } \\
\text { on set after horse- } \\
\text { riding. Recent on set of } \\
\text { pain down R leg to knee } \\
\text { \& stiff R ankle SLR } 90-90 .\end{array}$ & $10 \mathrm{yrs}$. & $\mathbf{L}$ & $\begin{array}{l}\text { Large posterior disc protrusion } \mathrm{L} 4-5 \\
\text { obliterating } \mathrm{L} \text { nerve root sheath. }\end{array}$ & $\begin{array}{ll}\text { Anterior spinal fusion l-4-5 } \\
\text { and disc excision. }\end{array}$ & Good recovery \\
\hline & & & . & . & & . & 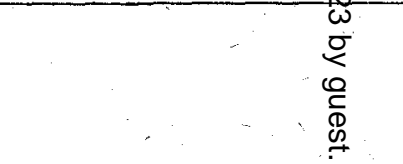 & $\therefore$ \\
\hline
\end{tabular}




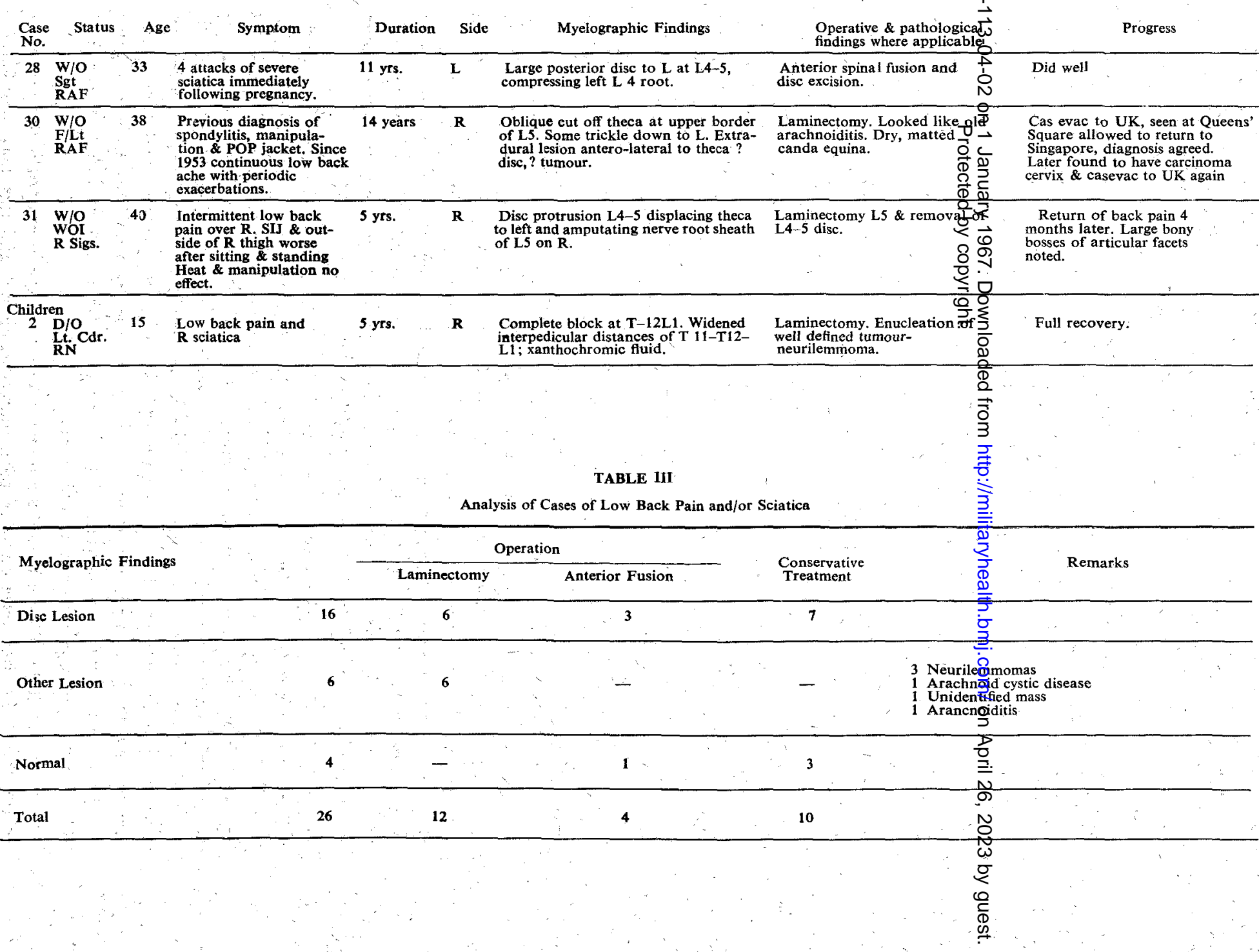




\section{Discussion}

The first question is whether myelography is of value in the diagnosis of disc lesions, as the clinical picture and natural history often allow management to be based on clinical judgement. This small series has at least taught us that among a small group of twenty six patients, all of whom at some time had been regarded as disc problems, other pathology was discovered in six. Without myelography four of these six would certainly have continued with chronic disability and pain for a varying time as on neurological grounds they would not have been explored. Indeed, five of the group had already borne their complaints for a number of years. The girl with the large neurilemmoma perhaps deserves comment. She never presented neurological signs despite the advanced development of her tumour and general disturbance, as evidenced by the high cerebro-spinal fluid protein and xanthochromia. It is possible that the next stage of her illness would have been a progressive paraplegia which despite surgery, could have left persistent stigmata.

Notwithstanding the apparently clear cut diagnoses to be made myelographically in many of these patients, it is clear that the clinical picture is neither always so obvious nor the management so simple and search was made in the X-ray films for other factors which might influence events. From this emerged three observations which may be of importance.. First, in a large proportion of disc lesions at the penultimate interval there wasd isc-space narrowing at the lumbo-sacral disc-space. This is well shown here and underlines one of the misleading characteristics of plain films, emphasising that the finding of an abnormal disc-space does not immediately indict it as a source of symptoms at that level. Campbell Golding (1959) reported finding forty-four such examples in films of one hundred patients examined by barium enema. Bauer (1960), Massie (1959) and Harmon \& Abel (1963) have all pointed out the frequent occurence of marked degeneration of the caudal disc in persons with myelographic protrusions only at the penultimate space. Interest had been revived recently in interpreting the plain films in lumbar disc disorders. Gurdjian et al (1961) noted protrusions at the penultimate level in 6.7 per cent of all patients and in 32.8 per cent of patients with narrowing of the caudal disc-space. Harmon (1963) says that acquired narrowing of the caudal discspace is a common observation in films of middle-aged women, is not always associated with symptoms, and that in a number myelography shows a protrusion at the level above. He also remarks that degeneration is sometimes generalised in the lumbar spine as judged by disc-space narrowing, arthrosis and vertebral instability.

Second, where oblique views were taken in such cases, it was possible to demonstrate corresponding subluxation of the apophyseal joints. It is widely thought to contribute to chronic back pain in these patients but it is seen to persist after successful recovery from disc excision. It would seem likely that the effects of subluxation are neutralised by the considerable reduction of movement which remains jn such a segment after operation. However, subluxation of the apophyseal joints is a natural sequel of narrowing of the intervertebral disc-space and will lead to osteoarthrosis from faulty weight transmission. The loss of motion which consequently occurs at this level-which has been seen on cine-radiography-undoubtedly throws increased strain on the level above and would predispose to trouble there.

The third observation is that in a number of instances, the inferior articular processes of the fourth lumbar vertebra were particularly prominent and this may well have a 
bearing on the pathogenesis of symptoms in the manner suggested by Highman (1965). An example is Case 31 whose low back pain recurred after disc excision by an interlaminar approach. The bosses of bone were seen in subsequent films (Figs. 4.1, 4.2). By contrast, Case 1-a Sergeant of Royal Marines-also showed large bosses of bone but his disc was excised by hemilaminectomy. He returned to his extremely arduous duties with the Special Boat Section. One asks oneself if the removal of rather more bone allows an increase in the dimensions of the canal so that the bony encroachment becomes of no significance.

The occurrence and severity of symptoms depend, as in all space-occupying tumours, on the amount of available space: If the spinal canal is abnormally narrow (Highman 1965 ) or encroached upon by bony prominences, it will follow that relatively small disc protrusions could be expected to cause symptoms. We see the reverse of this above the third lumbar segment where protrusions require to be relatively large to provoke symptoms. The presence of a myelographically proven disc prolapse in a roomy canal need not lead to operation and there is a need to assess the protrusion in terms of the canal rather than on its absolute appearance. We have elsewhere seen the extreme of this where complete spinal block due to a symptomless lumbar disc was discovered at ascending myelography during the assessment of a complete brachial plexus lesion. Even with complete occlusion of the sub-arachnoid space, cauda-equina neurological signs do not necessarily follow. Robinson (1965) described fifty two cases of complete myelographic block by disc prolapse in which only seventeen had cauda-equina compression syndrome.

Reference has been made to the close resemblance between the myelographic pictures due to intra-spinal tumours and disc protrusions which, after all, are only one variety of extradural tumour. They are distinguishable chiefly from their position, the disc protrusions being immediately posterior to an intervertebral space. There are two circumstances in which they cannot be differentiated by this method. The first is when there is complete spinal block, as shown by the similar appearances in Cases 32 and 30 (Figs. 6.1, 6.2 and 11.1). The second is when an extradural lesion is not at the level of a disc space or is not anterior or antero-lateral to the theca. Then it may be either a piece of sequestrated disc material or a rounded tumour as in Case 10 (Fig. 8.) Their appearances in antero-posterior projection are very similar. In both these instances where the myelographic appearances are sufficiently equivocal, exploration is desirable and certainly in such cases anterior disc excision has no place.

In conclusion it may be said that an increased curiosity towards patients with chronic back ache, with or without root pain, has lead to an attempt to define the pathology objectively by myelography which we have found rewarding.

\section{Summary}

An account is given of a group of thirty five myelograms performed during an eighteen month period in this hospital. Technique and findings are described and the value of this examination discussed. In particular, of 26 cases of low back pain and sciatica, six were shown to be due to lesions other than disc disease.

\section{Acknowledgements}

We are happy to acknowledge the generous encouragement of Major-General 
P. R. Wheatley, at the time Consulting Surgeon, Far East Land Forces. We are also grateful to Mr. J. E. A. O'Connell for the photograph of Case 2 on whom he operated, to the Edinburgh Royal Infirmary for autopsy details in case 11 and to the Royal Naval School of Radiography for assistance with the illustrations.

\section{REFERENCES}

BARR, J. S. (1947) J. Bone and Jt. Surg. 29, 429.

BAUER D. DE F. (1960). Lumbar Discography and Low Back Pain (Thomas Springfield, Illinois).

BeGG, A. C., FAlConer, M. A. and McGeorge M. (1946). Brit. J. Surg., 34, 141.

EPSTEIn, B. S. (1955). The Spine. (Lea and Febiger, Philadelphia) p. 138.

Gurdian, E. S., Webster, J. E., Ostrowski, A. Z., Hardy, W. G., Lindner D. W. and Thomas L. M. (1961). J. Trauma, 1, 158.

HARMON, P. H. (1962). Ann. Surg., 156, 767.

HARMON, A. C. and ABEL, M. S. (1963). Clin. Orthopaed. 28.

HAMPton, A. O. and Robinson, J. M. (1936). Amer. J. Roentgenol. 36, 782.

Hesketh, K. T. (1965). J. Neurol., Neurosurg. and Psych., 28, 445.

Highman, J. H. (1965). Clin. Radiol, 16, 106.

LANSCHE, W. E. and FoRd, L. T. (1960). J. Bone and Jt. Surg., 42A, 193.

MAssie, W. K. (1959). J. Bone and Jt. Surg., 41A, 1358 (abstract).

O'CONNELL, J. E. A. (1951). J. Bone and Jt. Surg., 33B, 8.

ROAF, J. (1959). Amer. J. Surg., 97, 388.

RoBinson, R. G. (1965). Brit. J. Surg., 52, 858.

SCHLESINGER, E. B. (1962). J. Trauma, 2, 162.

SiCARD, J. A. and ForESTIER, J. (1923). Bull. et Mem. d.Soc. Radiol. Med. de France, 11, 148.

Swann, G. F. (1963). Personal Communication.

WILDE, O, (1895) The Importance of Being Earnest, Act 1, in "Three Comedies", Ed. Earle, G.P.W. (Ginn \& Co. Ltd, London). p. 224.

\section{University of London}

Lieutenant-General Sir Robert Drew has been re-elected a member of the Governing Body of the British Postgraduate Medical Federation, on which he has served from 1955-57.

$\mathrm{He}$ has also been re-appointed to the Committee of Management of the Royal Postgraduate Medical School, on which he served from 1955-57 and 1959-63. 